Original Research

\title{
Yield-Scaled Nitrous Oxide Emission from Soils Depending on Nitrogen Use Efficiency Characteristics
}

\author{
Antoni Faber ${ }^{\text {*, Zuzanna Jarosz }}{ }^{1}$, Anna Jędrejek ${ }^{1}$, Agnieszka Rutkowska² \\ ${ }^{1}$ Department of Bioeconomy and Systems Analysis, Institute of Soil Science and Plant Cultivation \\ - State Research Institute, Puławy, Poland \\ ${ }^{2}$ Department of Plant Nutrition and Fertilization, Institute of Soil Science and Plant Cultivation \\ - State Research Institute, Puławy, Poland
}

Received: 7 May 2018

Accepted: 24 July 2018

\begin{abstract}
Nitrogen fertilization of agricultural crops increases nitrous oxide $\left(\mathrm{N}_{2} \mathrm{O}\right)$ emissions from soils. The data used in this study were obtained from a long-term field experiment for corn, winter wheat and rapeseed cultivated on loam and sandy loam soils, and fertilized with the recommended nitrogen doses $\left(\mathrm{kg} \mathrm{N} \mathrm{ha}^{1}\right)$ of 150, 120 and 150, respectively. The purpose of the study was to determine the relationship between yield-scaled $\mathrm{N}_{2} \mathrm{O}$ emissions (Eys) and nitrogen yield (Yn), as well as nitrogen use efficiency (NUE) and nitrogen surplus (Ns). It was found that the provisionally determined desired yield values ( $\left.\mathrm{Yn}>80 \mathrm{~kg} \mathrm{~N} \mathrm{ha}^{-1}\right)$, NUE $(50-90 \%)$ and $\mathrm{N}$ surplus $\left(\mathrm{Ns}^{\circ}<80 \mathrm{~kg} \mathrm{~N} \mathrm{ha}^{-1}\right)$ can be considered as nitrogen utilization efficiency characteristics, reducing yield-scaled $\mathrm{N}_{2} \mathrm{O}$ emissions. Our study showed that these emissions for desired parameters Yn, NUE and Ns were $\leq 25.6$, 28.3-18.6 and $\leq 30.9$ g N $\mathrm{N}_{2} \mathrm{O} \_\mathrm{N} \mathrm{kg}$ $\mathrm{Yn}^{-1}$, respectively. Estimated Eys were 1.5-2.6 time higher than the minimum emission and 2.2-3.6 times lower than the maximum emission recorded in the analyzed data series. In conclusion, the reduction of nitrogen surplus in our field experiment, significant for environmental protection, did not result in loss of crop yields; on the contrary, it led to their growth.
\end{abstract}

Keywords: $\mathrm{N}_{2} \mathrm{O}$; emission; yield-scaled; NUE

\section{Introduction}

Fertilization of crops with nitrogen $(\mathrm{N})$ contained in natural and/or mineral fertilizers is a common practice that has long been used in agriculture. It is due to the fact that the application of this element in

*e-mail: faber@iung.pulawy.pl a dose adapted to the plant's nutritional needs has a strong yielding effect. However, plants usually take up and process into yield production only a part of the nitrogen applied. The level of $\mathrm{N}$ uptake is plant speciesspecific and depends on numerous factors, especially $\mathrm{N}$ input, soil characteristics and weather conditions [1]. Recently, the efficiency of nitrogen utilization contained in applied fertilizers has been described by the following parameters: nitrogen yield (Yn), nitrogen use efficiency (NUE) and nitrogen surplus (Ns). It has been 
assumed that arable crops use in the most productive way the nitrogen contained in natural and/or mineral fertilizers when $\mathrm{Yn}>80 \mathrm{~kg} \mathrm{~N} \mathrm{ha}^{-1}$, NUE $=50-90 \%$ and $\mathrm{Ns}^{\circ}<80 \mathrm{~kg} \mathrm{~N}^{-1}$ [2]. Nitrogen surplus (Ns) may partially enrich the soil with ammonium nitrogen; however, most of it is lost by leaching into the water in the nitrate nitrogen form, or emitted to the atmosphere in the form of ammonia and/or nitrous oxide $\left(\mathrm{N}_{2} \mathrm{O}\right)$. Nitrogen losses occurring in the waters contribute to their eutrophication, while gaseous losses cause an intensification of climate change advances. Agriculture, which is one of the major ammonia and $\mathrm{N}_{2} \mathrm{O}$ emitters, is required to report these emissions and also to promote practices that limit the leaching and emission of nitrogen compounds to the environment [3, 4]. These activities are primarily aimed at reducing the environmental burden of potentially harmful reactive nitrogen compounds.

The purpose of this study was to determine the relationship between yield-scaled $\mathrm{N}_{2} \mathrm{O}$ emissions from soils, on which winter wheat, grain maize and oilseed rape were grown, and nitrogen yield (Yn), nitrogen use efficiency (NUE) and nitrogen surplus (Ns). Moreover, the values of the above indicators of the efficiency of nitrogen utilization, considered desirable to ensure adequate efficiency of $\mathrm{N}$ utilization, were verified. It was hypothetically assumed that for all plant crops under study, characterized by diversified nitrogen demand, it is possible to describe the common regression equations.

\section{Materials and Methods}

Field experiments were carried out at two experimental stations of the Institute of Soil Science and Plant Cultivation - State Research Institute in Puławy, Poland between 2003 and 2013. Experiments were located in Baborówko, western Poland $\left(19^{\circ} 12^{\prime} \mathrm{E}\right.$, $52^{\circ} 01^{\prime} \mathrm{N}$ ), on loam (pseudopodzol and black earth) and in Grabów, eastern Poland $\left(19^{\circ} 37^{\prime} \mathrm{E}, 52^{\circ} 37^{\prime} \mathrm{N}\right)$, on heterogeneous sandy loam and loam (brown type). In two factorial experiments, four crops were grown each year in the following rotation: winter oilseed rape - winter wheat - corn - spring barley. The first factor was $\mathrm{P}, \mathrm{K}, \mathrm{Mg}$, and $\mathrm{Ca}$ fertilization in plus or minus variants, and the second one were six levels of $\mathrm{N}$ fertilizers applied in split doses. For almost 30 years no manure was applied to the field experiments. In our analysis we used data from treatments with the supply of $\mathrm{P}, \mathrm{K}, \mathrm{Ca}, \mathrm{Mg}$ and the following rates of nitrogen $\left(\mathrm{kg} \mathrm{N} \mathrm{ha}^{-1}\right)$ : oilseed rape -150 , winter wheat -120 and corn -150 . The nitrogen doses were adapted to the average yields obtained for the conducted field experiment. The data used in our analyses included yields of main products ( $\left.\mathrm{Yg}, \mathrm{t} \mathrm{ha}^{-1}\right)$, yields of by-products $\left(\mathrm{t} \mathrm{ha} \mathrm{h}^{-1}\right)$ and nitrogen content in main products (\%). On the basis of these data, the nitrogen use efficiency parameters were estimated for grains.
Nitrogen utilization efficiency (NUE, \%) was assessed by the formula according to the EU nitrogen expert panel [2]:

$$
\mathrm{NUE}=\frac{\mathrm{Yn}}{\mathrm{F}} \times 100
$$

...where $\mathrm{Yn}\left(\mathrm{kg} \mathrm{N} \mathrm{ha}^{-1}\right)$ - nitrogen yield and $\mathrm{F}\left(\mathrm{kg} \mathrm{N} \mathrm{a}^{-1}\right)$ $-\mathrm{N}$ dose plus $\mathrm{N}$ from soil deposition $\left(14 \mathrm{~kg} \mathrm{ha}^{-1}\right)$. Thus, defined NUE is usually interpreted as the efficiency of $\mathrm{N}$ uptake by plants.

Nitrogen yield (Yn, $\mathrm{kg} \mathrm{N} \mathrm{ha}^{-1}$ ) was calculated by the formula:

\section{Yn $=$ grain yield $\times \mathrm{N}$ content in grains}

Nitrogen surplus (Ns, $\mathrm{kg} \mathrm{N} \mathrm{ha}^{-1}$ ) was assessed by the formula according:

$$
\mathrm{Ns}=\mathrm{F}-\mathrm{Yn}
$$

Ns is usually interpreted as a partial nitrogen balance. In the crops located on arable lands, about $80-100 \%$ of Ns may leach into the waters [5].

To be able to use the presented parameters (Yn, NUE and Ns) in the evaluation of nitrogen fertilization efficiency, it was temporarily assumed that the desired values for them should be: $Y n>80 \mathrm{~kg} \mathrm{~N} \mathrm{ha}{ }^{1}$, NUE $=50-90 \%$ and $\mathrm{Ns}^{\circ}<80 \mathrm{~kg} \mathrm{~N} \mathrm{ha}^{-1}[2]$.

Direct and indirect $\mathrm{N}_{2} \mathrm{O}$ emissions from soil were calculated according to the IPCC tier 1 methodology [3] using a BIOGRACE spreadsheet [6]. In the calculations, the amount of nitrogen contributed by mineral fertilizers, nitrogen interception (natural manure was not used) and straw was included.

The yield-scaled $\mathrm{N}_{2} \mathrm{O}$ emission $\left(\mathrm{g} \mathrm{N}_{2} \mathrm{O}_{-} \mathrm{N} \mathrm{kg}^{-1} \mathrm{Yn}\right)$ was estimated by the formula:

$$
\text { Eys }=\frac{\text { Emission } \mathrm{kg} \mathrm{N}_{2} \mathrm{O} \_\mathrm{N} \mathrm{ha}^{-1} * 1000}{\mathrm{Yn}}
$$

Statistical analyses were performed for a total of three studied crop plants using Statgraphics Centurion software ver. 16.1.11.-

\section{Results and Discussion}

In the analyzed set, the corn yields (Yg) varied widely from 1.72 to $15.18 \mathrm{t} \mathrm{ha}^{-1}$, with a median value of $8.11 \pm 2.21 \mathrm{t} \mathrm{ha}^{-1}$ (Median \pm MAD) (Table 1). Nitrogen yields (Yn) were generally above the desired value of $80 \mathrm{~kg} \mathrm{~N} \mathrm{ha}^{-1}$, with a median of $124 \pm 28 \mathrm{~kg} \mathrm{~N} \mathrm{ha}^{-1}$. However, during the experiment period there were limiting factors (water availability), and reducing yields (weeds, diseases, and pests), which resulted in a minimum nitrogen intake of only $27.0 \mathrm{~kg} \mathrm{~N} \mathrm{ha}^{-1}$ 
for the total nitrogen dose of $150 \mathrm{~kg} \mathrm{~N} \mathrm{ha-1}$ in the applied fertilizer. On the other hand, in yield-favorable conditions the $\mathrm{N}$ uptake reached a maximum value of $195 \mathrm{~kg} \mathrm{~N} \mathrm{ha}{ }^{-1}$. The median NUE value $(82.5 \pm 18.5 \%)$ was within the range of the desired values $(50-90 \%)$. However, in some years the nitrogen dose was slightly too low because NUE was greater than $90 \%$. It also indicates that plants took nitrogen stored in the soil repository (nitrogen mining). The surplus nitrogen $\left(26.5 \pm 28.0 \mathrm{~kg} \mathrm{ha}^{-1}\right)$ was in the range of the desired values. The median yield-scaled $\mathrm{N}_{2} \mathrm{O}$ emission (Eys) was $18.9 \pm 2.7 \mathrm{~g} \mathrm{~N} \mathrm{~N}_{2} \mathrm{O}_{-} \mathrm{N} \mathrm{kg}^{-1} \mathrm{Yn}$, with a minimummaximum range of $12.1-67.8 \mathrm{~g} \mathrm{~N} \mathrm{~N}_{2} \mathrm{O} \mathrm{N} \mathrm{kg}^{-1} \mathrm{Yn}$. In general, the applied nitrogen dose plus interception $\left(150+14 \mathrm{~kg} \mathrm{~N} \mathrm{ha}^{-1}\right)$ was slightly underestimated in relation to the maize fertilization needs; however, its increase could simultaneously lead to an unwanted increase in the Ns and Eys values.

The yields of winter wheat grain $(\mathrm{Yg})$ in the analyzed collection varied from 2.51 to $8.62 \mathrm{t} \mathrm{ha}^{-1}$, with a median value of $5.18 \pm 1.41 \mathrm{t} \mathrm{ha}^{-1}$ (Table 2). Nitrogen yields (Yn) were sometimes lower than the desired value $(80 \mathrm{~kg} \mathrm{~N}$ $\mathrm{ha}^{-1}$ ), with a median of $92 \pm 24 \mathrm{~kg} \mathrm{~N} \mathrm{ha}^{-1}$. Nevertheless, as in the case of maize, factors strongly limiting yield of grain and nitrogen occurred in some years during the field experiment. Consequently, the minimum Yn was only $44.0 \mathrm{~kg} \mathrm{~N} \mathrm{ha}^{-1}$ for the total nitrogen dose of $120 \mathrm{~kg} \mathrm{~N} \mathrm{ha}{ }^{-1}$ in the applied fertilizer. On the other hand, in yield-favorable conditions the $\mathrm{N}$ intake reached a maximum value of $150 \mathrm{~kg} \mathrm{~N} \mathrm{ha}{ }^{-1}$. The median NUE value $(76 \pm 21 \%)$ was in the range of desirable values (50-90\%). Nevertheless, in some years NUE was greater than $90 \%$, which indicates that the dose of $\mathrm{N}$ used was slightly too low, and the plants used nitrogen accumulated in the soil. The median nitrogen surplus (Ns) value was $29 \pm 24 \mathrm{~kg} \mathrm{ha}^{-1}$ and fitted to the range of desirable values. The median yield-scaled $\mathrm{N}_{2} \mathrm{O}$ emission (Eys) was 22.4 $\pm 4.1 \mathrm{~g} \mathrm{~N}_{2} \mathrm{O}_{-} \mathrm{N} \mathrm{kg}^{-1} \mathrm{Yn}$, with a min-max range of 15.8-38.0 $\mathrm{g} \mathrm{N}_{2} \mathrm{O}_{-} \mathrm{N} \mathrm{kg}^{-1} \mathrm{Yn}$. In conclusion, it can be seen that winter wheat absorbed less total nitrogen than maize because in some years Yn for wheat was below $80 \mathrm{~kg} \mathrm{~N} \mathrm{ha}^{-1}$.

The yields of winter oilseed rape grains (Yg) in the analyzed collection oscillated between 1.25 and $4.62 \mathrm{t} \mathrm{ha}^{-1}$, with a median value of $2.88 \pm 0.79 \mathrm{t} \mathrm{ha}^{-1}$ (Table 3). Estimated nitrogen yields (Yn) were higher than the desired value of $80 \mathrm{~kg} \mathrm{~N} \mathrm{ha}{ }^{-1}$, with a median value of $98 \pm 23 \mathrm{~kg} \mathrm{~N} \mathrm{ha}^{-1}$. However, as in the case of

Table 1. Parameters of yields, nitrogen use efficiency and emissions for grain maize $(n=44)$.

\begin{tabular}{|c|c|c|c|c|c|c|}
\hline \multirow{2}{*}{ Parameters } & Yg & Yn & NUE & Ns & E & Eys \\
\cline { 2 - 7 } & $\left(\mathrm{t} \mathrm{ha}^{-1}\right)$ & $\left(\mathrm{kg} \mathrm{ha}^{-1}\right)$ & $(\%)$ & $\left(\mathrm{kg} \mathrm{ha}^{-1}\right)$ & $\left(\mathrm{kg} \mathrm{N}_{2} \mathrm{O} \_\mathrm{N} \mathrm{ha}^{-1}\right)$ & $\left(\mathrm{g} \mathrm{N}_{2} \mathrm{O}_{-} \mathrm{N} \mathrm{kg}^{-1} \mathrm{Yn}\right)$ \\
\hline Median & 8.11 & 123.5 & 82.5 & 26.5 & 2.31 & 18.9 \\
\hline MAD & 2.21 & 28.0 & 18.5 & 28.0 & 0.20 & 2.70 \\
\hline Minimum & 1.72 & 27.0 & 18.0 & -45.0 & 1.60 & 12.1 \\
\hline Maximum & 15.18 & 195.0 & 130 & 123.0 & 2.90 & 67.8 \\
\hline
\end{tabular}

Table 2. Parameters of yields, nitrogen use efficiency and emissions for winter wheat $(n=44)$.

\begin{tabular}{|c|c|c|c|c|c|c|}
\hline \multirow{2}{*}{ Parameters } & Yg & Yn & NUE & Ns & E & Eys \\
\cline { 2 - 7 } & $\left(\mathrm{tha}^{-1}\right)$ & $\left(\mathrm{kg} \mathrm{ha}^{-1}\right)$ & $(\%)$ & $\left(\mathrm{kg} \mathrm{ha}^{-1}\right)$ & $\left(\mathrm{kg} \mathrm{N}_{2} \mathrm{O}_{-} \mathrm{N} \mathrm{ha}^{-1}\right)$ & $\left(\mathrm{g} \mathrm{N}_{2} \mathrm{O}_{-} \mathrm{N} \mathrm{kg}^{-1} \mathrm{Yn}\right)$ \\
\hline Median & 5.18 & 91.5 & 76.0 & 29.0 & 2.0 & 22.4 \\
\hline MAD & 1.41 & 24.5 & 20.5 & 24.5 & 0.17 & 4.1 \\
\hline Minimum & 2.51 & 44.0 & 37.0 & -30.0 & 1.67 & 15.8 \\
\hline Maximum & 8.62 & 150 & 125.0 & 76.0 & 2.42 & 38.0 \\
\hline
\end{tabular}

Table 3. Parameters of yields, nitrogen use efficiency and emissions for oilseed rape $(n=44)$.

\begin{tabular}{|c|c|c|c|c|c|c|}
\hline \multirow{2}{*}{ Parameters } & Yg & Yn & NUE & Ns & E & Eys \\
\cline { 2 - 7 } & $\left(\mathrm{t} \mathrm{ha}^{-1}\right)$ & $\left(\mathrm{kg} \mathrm{ha}^{-1}\right)$ & $(\%)$ & $\left(\mathrm{kg} \mathrm{ha}^{-1}\right)$ & $\left(\mathrm{kg} \mathrm{N}_{2} \mathrm{O}_{-} \mathrm{N} \mathrm{ha}^{-1}\right)$ & $\left(\mathrm{g} \mathrm{N}_{2} \mathrm{O}_{-} \mathrm{N} \mathrm{kg}^{-1} \mathrm{Yn}\right)$ \\
\hline Median & 2.88 & 97.5 & 64.5 & 53.0 & 2.27 & 24.0 \\
\hline MAD & 0.79 & 23.0 & 15.0 & 22.5 & 0.17 & 3.7 \\
\hline Minimum & 1.25 & 42.0 & 28.0 & -11.0 & 1.48 & 16.2 \\
\hline Maximum & 4.62 & 161.0 & 107.0 & 108.8 & 2.65 & 46.8 \\
\hline
\end{tabular}


maize and wheat, factors strongly limiting yield of grain and nitrogen occurred in some years during the field experiment. This resulted in a minimum Yn of only $42.0 \mathrm{~kg} \mathrm{~N} \mathrm{ha}^{-1}$ for the total nitrogen dose of $150 \mathrm{~kg} \mathrm{~N} \mathrm{ha}{ }^{-1}$ in the applied fertilizer. In turn, under good yielding conditions the intake was up to $161 \mathrm{~kg} \mathrm{~N} \mathrm{ha}{ }^{-1}$. The median NUE $(64.5 \pm 15 \%)$ and Ns $\left(53 \pm 22 \mathrm{~kg} \mathrm{~N} \mathrm{ha}^{-1}\right)$ values were well within the range of desired values. The median yield-scaled $\mathrm{N}_{2} \mathrm{O}$ emission (Eys) value was $22.4 \pm 4.1 \mathrm{~g} \mathrm{~N}_{2} \mathrm{O}_{-} \mathrm{N} \mathrm{kg}^{-1} \mathrm{Yn}$, with a min-max range of 15.8-38.0 g $\overline{\mathrm{N}}_{2} \mathrm{O}_{-} \mathrm{N} \mathrm{kg}^{-1} \mathrm{Yn}$. In summary, the applied nitrogen dose plus interception $\left(150+14 \mathrm{~kg} \mathrm{~N} \mathrm{ha}^{-1}\right)$ was sufficiently adjusted to the fertilizer needs of oilseed rape.

The presented data (Tables 1-3) were characterized by sufficient variability for conducting the intended analyses. The nitrogen yield-forming effects estimated on their basis were as follows: $14.2,17.9$ and $32.9 \mathrm{~kg}$ of grain $\mathrm{kg}^{-1} \mathrm{~N}$ for maize, winter wheat and winter oilseed rape, respectively. The above values were slightly better than the average values given for large datasets (15.5, 18.9 and $33.6 \mathrm{~kg}$ of grain $\mathrm{kg}^{-1} \mathrm{~N}$ for maize, winter wheat and winter oilseed rape, respectively).

The regression between yield-scaled $\mathrm{N}_{2} \mathrm{O}$ emissions from soil (Eys) and nitrogen yield (Yn) was described by a reciprocal-X model according to the equation Eys $=\mathrm{a}+\frac{\mathrm{b}}{\mathrm{Yn}}$ (Fig. 1). The curve was well adjusted, as indicated by the high value of its coefficient of determination $\left(\mathrm{R}^{2}=95.1 \%\right)$. According to the regression equation, for the desired nitrogen yield value ( $\mathrm{Yn}>80 \mathrm{~kg}$ $\mathrm{N} \mathrm{ha}^{-1}$ ), the Eys values will be $\leq 25.6 \mathrm{~g} \mathrm{~N}_{2} \mathrm{O}_{-} \mathrm{N} \mathrm{kg}^{-1} \mathrm{Yn}$.

The regression between Eys and NUE was described by the same type of model based on the equation Eys $=a+\frac{b}{\text { NUE }}$ (Fig. 2). The coefficient of determination was $\mathrm{R}^{2}=97.0 \%$, showing a good curve fitting, and the Eys values estimated from the curve ranged from 28.3 to $18.6 \mathrm{~g} \mathrm{~N}_{2} \mathrm{O} \mathrm{kg}^{-1} \mathrm{Yn}$ for the desired NUE value $(50-90 \%)$.

The regression between Eys and Ns was also described by reciprocal-Y model based on the equation

\section{Emission (g N2O_N/kg Yn)}

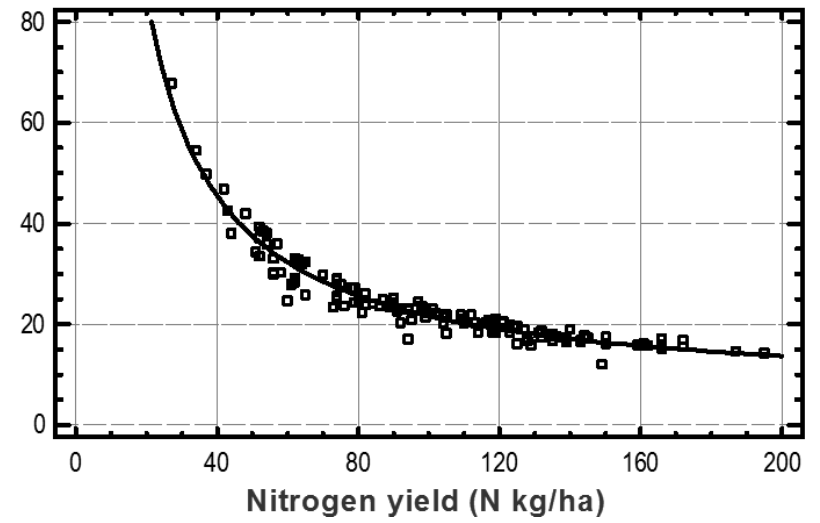

Fig. 1. Regression between yield-scaled $\mathrm{N}_{2} \mathrm{O}_{-} \mathrm{N}$ emissions (Eys) and nitrogen yield $(\mathrm{Yn})($ Eys $=5.78+1587 / \overline{\mathrm{Y}} \mathrm{n})$.
Emission (g N2O_N/kg Yn

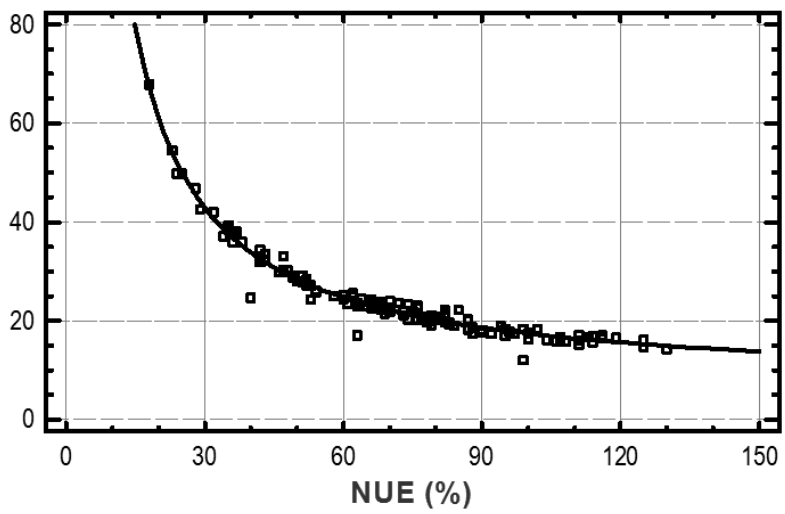

Fig. 2. Regression between yield-scaled $\mathrm{N}_{2} \mathrm{O}_{-} \mathrm{N}$ emissions (Eys) and nitrogen use efficiency (NUE) (Eys $=6 . \overline{52}+1091 / \mathrm{NUE})$.

Eys $=\frac{1}{\mathrm{a}-\mathrm{b} * \mathrm{Ns}}$ (Fig. 3). The coefficient of determination was $\mathrm{R}^{2}=88.3 \%$, indicating a good curve fitting. The regression curve showed that for $\mathrm{Ns}>80 \mathrm{~kg} \mathrm{~N}^{-1}$ the emission values (Eys) increase rapidly. For Ns values lower than $80 \mathrm{~kg} \mathrm{~N}^{-1}$ the Eys values were below $30.9 \mathrm{~g} \mathrm{~N}_{2} \mathrm{O} \_\mathrm{N} \mathrm{kg}^{-1} \mathrm{Yn}$.

A farmer with the best own economic interest and for environmental reasons should potentially be willing to keep nitrogen surplus (Ns) as low as possible. In the simplest way, it can be implemented by applying nitrogen doses according to the current fertilizer recommendations. For the nitrogen doses used in our field experiment, where the long-term variability of the nitrogen application efficiency characteristics was random, maintaining nitrogen surplus at $39 \pm 6.27 \mathrm{~kg} \mathrm{~N}$ ha $^{-1}$ provided yields in the range of $54-60 \%$ of the relative maximum harvest (Fig. 4). Thus, our results confirm that efforts aimed at improving the economic efficiency of crop fertilization are consistent with measures to protect the environment, water quality, and climate.

\section{Emission (g N2O_N/kg Yn)}

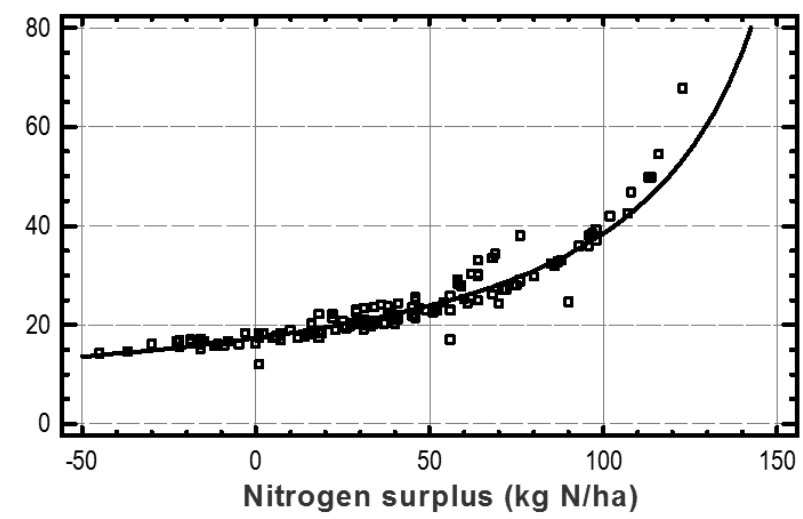

Fig. 3. Regression between yield-scaled $\mathrm{N}_{2} \mathrm{O} \_\mathrm{N}$ emissions (Eys) and nitrogen surplus (Ns) (Eys $=1 /\left(0.0577-0.000317^{*} \mathrm{Ns}\right)$. 


\section{Relative grain yield}

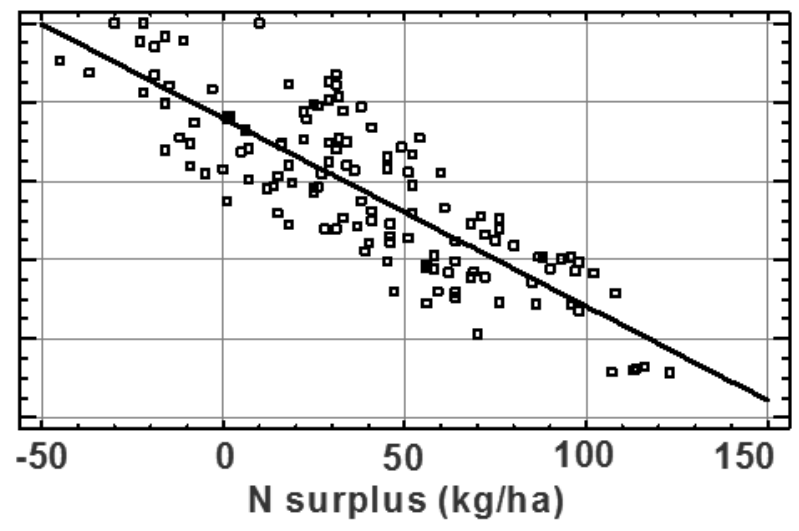

Fig. 4. Regression between relative grain yield (seeds) (Yg relative $)$ and nitrogen surplus $\left(\mathrm{Ns}, \mathrm{kg} \mathrm{ha}^{-1}\right)($ Yg relative $=0.759$ $0.00477 * \mathrm{Ns} ; \mathrm{r}^{2}=69.5 \%$ ).

In 2015, $\mathrm{N}_{2} \mathrm{O}$ emissions accounted for $4.9 \%$ of total greenhouse gas (GHGs) emissions in Poland [7]. The main sources of nitrous oxide emissions were agricultural land $(67.0 \%)$ and manure management (11.0\%). Hence, agriculture generated $78 \%$ of the total emissions of $\mathrm{N}_{2} \mathrm{O}$ in 2015. Due to the fact that this gas has a heat equivalent of 298 times higher than carbon dioxide, its emission contributes to the reduction of ozone in the stratosphere and significantly impacts climate change [4]. It is therefore understandable that attempts are being made to limit $\mathrm{N}_{2} \mathrm{O}$ emissions in agriculture due to the need to mitigate climate change.

Nitrous oxide emissions from agricultural land depend on several factors such as climate, soil granulometric composition, organic carbon content, and dose and type of applied fertilizer [8, 9]. Moreover, it has been found that emissions are clearly increasing as a result of the application of mineral and/or natural fertilizers [10-12]. The rate of this increase depends on the processes of nitrification and denitrification of nitrogen in the soil. These processes take place due to the activity of soil microorganisms and are part of the natural cycle of nitrogen transformation. Although the farmer has no direct impact on this cycle and $\mathrm{N}_{2} \mathrm{O}$ emissions, they can indirectly affect them by increasing NUE. This can be achieved by adapting an appropriate nitrogen dose to the fertilizing needs of the plant crops. For this purpose, commonly available systems of fertilizer recommendations and the long-term analysis of nitrogen use efficiency parameters can be helpful [2].

The conducted research shows that the methods of effective limiting of $\mathrm{N}_{2} \mathrm{O}$ emissions from fertilized soils are consistent with the activities promoting agronomic efficiency in general [13]. On the basis of the results of 19 studies, it was found that the yield-scaled $\mathrm{N}_{2} \mathrm{O}$ emissions (expressed as $\mathrm{g} \mathrm{N}_{2} \mathrm{O} \_\mathrm{N}$ per $\mathrm{kg}$ aboveground $\mathrm{N}$ uptake) are the lowest at medium $\mathrm{N}$ doses [14]. For example, a meta-analysis showed that at $\mathrm{N}$ dose of 150$200 \mathrm{~kg} \mathrm{~N}^{-1}$ the yield-scaled $\mathrm{N}_{2} \mathrm{O}$ emissions decreased by $37 \%$ in comparison to the non-fertilized control for rice cultivated in China [15]. Moreover, the lowest emissions from soil were observed for $\mathrm{N}$ doses between 100 and $150 \mathrm{~kg}$ of $\mathrm{N} \mathrm{ha}^{-1}$ in sub-Saharan Africa farming [16]. In general, the results of the above studies showed that the $\mathrm{N}$ dose that guarantees the optimal yield can simultaneously minimize yield-scaled $\mathrm{N}_{2} \mathrm{O}$ emissions from soil. This conclusion is very important because it contradicts the view that the only possible way to limit $\mathrm{N}_{2} \mathrm{O}$ emissions is to reduce nitrogen fertilizer dose. Furthermore, analysis of Eys is relevant in view of the global challenges of increasing food production and decreasing emissions concomitantly [17-19].

Despite the fact that recently the number of studies on yield-scaled $\mathrm{N}_{2} \mathrm{O}$ emissions have recently increased $[14,15,19-22]$, studies on the relationship between Eys and nitrogen efficiency characteristics are still rare. One of the few examples of this type of research is the meta-analysis of the correlation between yieldscaled $\mathrm{N}_{2} \mathrm{O}$ emissions and nitrogen surplus and nitrogen use efficiency as described by van Groenigen et al. [13]. The authors used data from 19 publications (147 observations) to estimate the relationship between Eys (expressed as $\mathrm{g} \mathrm{N}_{2} \mathrm{O}_{-} \mathrm{N}$ per $\mathrm{kg}^{-1}$ aboveground $\mathrm{N}$ uptake) and Ns and NUE. As a result, they found that the regression between Eys and Ns was curvilinear. The emission nearly didn't increase in the range of Eys between -150 and $10 \mathrm{~kg} \mathrm{~N} \mathrm{ha}^{-1}$, then it continued to grow rapidly curvilinear. Eventually, above the Ns value of 90 $\mathrm{kg} \mathrm{N} \mathrm{ha}{ }^{-1} \mathrm{~N}_{2} \mathrm{O}$ emissions increased threefold.

Our analyses were performed for nitrogen fertilizer doses of $120-150 \mathrm{~kg} \mathrm{~N} \mathrm{ha}^{-1}$, which according to literature should provide the lowest Eys $[15,16]$. The field experiment was conducted over a period of 12 years on the same light soils. Hence, the variability of yield (Yg and Yn), NUE and Ns were caused by the random yieldforming conditions.

In our study, the relationship between Eys and Ns was found to be quite similar to that described by van Groenigen et al. [13] (Fig. 3). In the Ns range from -50 to $10 \mathrm{~kg} \mathrm{~N} \mathrm{ha}^{-1}$, the emission increased by less than 1 $\mathrm{g} \mathrm{N}_{2} \mathrm{O} \_\mathrm{N} \mathrm{kg}{ }^{-1}$ Yn. Subsequently, curved and larger Eys increments started after exceeding $\mathrm{Ns}=50 \mathrm{~kg} \mathrm{~N}^{-1}$ (Fig. 3). In the study of van Groenigen et al. [13] the relationship between Eys and NUE was a negative linear regression in the NUE range of $20-75 \%$. In turn, in our research the range of NUE's variability was broader (18-130\%), and the obtained dependence was non-linear (Fig. 2). As shown in Figure 2, Eys was the lowest at NUE value close to $90 \%$.

In conclusion, our analyses, based on extensive data from the field experiment, demonstrated that the expected values of Yn, NUE, and Ns proposed by EU NEP [2] can also be regarded as the nitrogen efficiency characteristics that reduce the yield-scaled $\mathrm{N}_{2} \mathrm{O}$ emissions from soil. Moreover, it was found that the reduction of nitrogen surplus, and thus the Eys, was linked to an increase in relative grain yields (Fig. 4). Our results confirm the thesis of van Groenigen et al. [13], 
according to which actions aimed at effective reduction of $\mathrm{N}_{2} \mathrm{O}$ emissions from fertilized soils are coherent with methods promoting the agronomic effectiveness of fertilization in general.

\section{Conclusions}

Temporarily determined desired values of nitrogen yield $\left(\mathrm{Yn}>80 \mathrm{~kg} \mathrm{~N} \mathrm{ha}^{-1}\right)$, nitrogen use efficiency $(\mathrm{NUE}=50-90 \%)$ and nitrogen surplus $\left(\mathrm{Ns}<80 \mathrm{~kg} \mathrm{~N} \mathrm{ha}^{-1}\right)$ can be considered as nitrogen efficiency characteristics limiting yield-scaled $\mathrm{N}_{2} \mathrm{O}$ emissions (Eys) from soils. Our research showed that nitrous oxide emissions for desired parameters Yn, NUE and Ns were $\leq 25.6$, 28.3-18.6 and $\leq 30.9$ g $\mathrm{N}_{2} \mathrm{O}_{-} \mathrm{N} \mathrm{kg} \mathrm{kg}^{-1} \mathrm{Yn}$, respectively. The estimated emissions were 1.5-2.6 times higher than the minimum emissions and 2.2-3.6 times lower than the maximum in the analyzed data series. In conclusion, according to our results, keeping the surplus nitrogen as low as possible, which is important for environmental protection, does not have to result in yield reduction. On the contrary, it may lead to their growth.

\section{Acknowledgements}

Our research was conducted within task 2.6: Analysis of the possibilities for the reduction of GHG, ammonium and nitrate emissions from agriculture in the perspective of 2030 and 2050 of Multi-Annual Programme of Institute of Soil Science and Plant Cultivation - State Research Institute in Puławy assigned for 2016-2020.

\section{Conflict of Interest}

The authors declare no conflict of interest.

\section{References}

1. MASCLAUX-DAUBRESSE C., DANIEL-VEDELE F., DECHORGNAT J., CHARDON F., GAUFICHON L., SUZUKI A. Nitrogen uptake, assimilation and remobilization in plants: challenges for sustainable and productive agriculture. Annals of Botany, 105 (7), 1141, 2010.

2. EU NITROGEN EXPERT PANEL. Nitrogen Use Efficiency (NUE) an indicator for the utilization of nitrogen in food systems. Wageningen University, Alterra, Wageningen, Netherlands. 2015.

3. IPCC. $\mathrm{N}_{2} \mathrm{O}$ Emissions From Managed Soils, and $\mathrm{CO}_{2}$ Emissions From Lime and Urea Application. In Guidelines for National Greenhouse Gas Inventories, Eggleston H.S., Buendia L., Miwa K., Ngara T. and Tanabe K. (Eds.), Japan, IGES, 2006.

4. IPCC. Climate change 2007: The physical science basis. Solomon S., Qin D., Manning M., Chen Z., Marquis M., Averyt K.B., Tignor M., Miller H.L. (Eds.). Cambridge University Press, Cambridge, 2007.
5. BILlEN G., LASSALETTA L., GARNIER J. Some conceptual and methodological aspects of NUE of agrofood systems. The note at the attention of the EU N-expert panel. Windsor, Sept 15-16, 2014 [manuscript].

6. BIOGRACE, Harmonised Calculation of Biofuel Greenhouse Gas Emission in Europe. 2015. Available online: http://www.biograce.net/content/ ghgcalculationtools/recognisedtool (accessed on 02.03.2018)

7. OLECKA A., BEBKIEWICZ K., CHŁOPEK Z., JĘDRYSIAK P., KANAFA M., KARGULEWICZ I., RUTKOWSKI J., SĘDZIWA M., SKOŚKIEWICZ J., WAŚNIEWSKA S., ŻACZEK M. Poland's National Inventory Report 2017. Greenhouse gas inventory for 1988-2015. Submission under the UN Framework Convention on Climate Change and its Kyoto Protocol., Warsaw, KOBiZE, 559, 2017.

8. BOUWMAN A.F., BOUMANS L.J.M., BATJES N.H. Emissions of $\mathrm{N}_{2} \mathrm{O}$ and $\mathrm{NO}$ from fertilized fields: Summary of available measurement data. Global Biogeochem. Cycle, $16(4), 6,2002$.

9. BUTTERBACH-BAHL K., BAGGS E. M., DANNENMANN M., KIESE R., ZECHMEISTERBOLTENSTERN S. Nitrous oxide emissions from soils: how well do we understand the processes and their controls? Philosophical Transactions of the Royal Society B: Biological Sciences, 368 (1621), 20130122, 2013.

10. BOUWMAN A.F. Direct emission of nitrous oxide from agricultural soils. Nutrient Cycling in Agroecosystems, 46 (1), 53, 1996

11. FORSTER P., RAMASWAMY V., ARTAXO P., BERNTSEN T., BETTS R., FAHEY D., HAYWOOD J., LEAN J., LOWE D. C., MYHRE G., NGANGA J., PRINN R., RAGA G., SCHULZ M., VAN DORLAND $\mathrm{R}$. Changes in atmospheric constituents and in radiative forcing. In: Climate Change 2007: The Physical Science Basis Contribution of Working Group I to the Fourth Assessment Report of the Intergovernmental Panel on Climate Change; Solomon S., Qin D., Manning M., Chen Z., Marquis M., Averyt K.B., Tignor M., Miller H. L. (Eds.). United Kingdom and New York, IPCC, 129, 2007.

12. SNYDER C. S., BRUULSEMA T. W., JENSEN T.L., FIXEN P.E. Review of greenhouse gas emissions from crop production systems and fertilizer management effects. Agriculture, Ecosystems and Environment, 133 (3-4), 247, 2009.

13. VAN GROENIGEN W. J., OENEMA O., VAN GROENIGEN K. J., VELTHOF G., VAN KESSEL C. Best Nitrogen Management Practices to Decrease Greenhouse Gas Emissions. Better Crops, 95 (2), 16, 2011.

14. QIN S., WANG Y., HU C., OENEMA O., LI X., ZHANG Y., DONG W. Yield-scaled $\mathrm{N}_{2} \mathrm{O}$ emissions in a winter wheat-summer corn double-cropping system. Atmospheric Environment, 55, 240, 2012.

15. FENG J., CHEN C., ZHANG Y., SONG Z., DENG A., ZHENG C., ZHANG W. Impacts of cropping practices on yield-scaled greenhouse gas emissions from rice fields in China: A meta-analysis. Agriculture, Ecosystems and Environment, 164, 220, 2013.

16. KIM D.G., THOMAS A.D., PELSTER D., ROSENSTOCK T.S., SANZ-COBENA A. Greenhouse gas emissions from natural ecosystems and agricultural lands in sub-Saharan Africa: Synthesis of available data and suggestions for further research. Biogeosciences 13(16), 4789, 2016.

17. FOLEY J.A., RAMANKUTTY N., BRAUMAN K.A., CASSIDY E.S., GERBER J.S., JOHNSTON M., 
MUELLER N.D., O'CONNELL C., RAY D.K., WEST P.C., BALZER C., BENNETT E.M., CARPENTER S.R., HILL J., MONFREDA C., POLASKY S., ROCKSTRÖM J., SHEEHAN J., SIEBERT S., TILMAN D., ZAKS D.P. Solutions for a cultivated planet. Nature, 478 (7369), 337, 2011.

18. VAN KESSEL C., VENTEREA R., SIX J., ADVIENTOBORBE M.A., LINQUIST B., VAN GROENIGEN K.J. Climate, duration, and $\mathrm{N}$ placement determine $\mathrm{N}_{2} \mathrm{O}$ emissions in reduced tillage systems: A meta-analysis. Global Change Biology, 19 (1), 33, 2013.

19. SAINJU U.M. A global meta-analysis on the impact of management practices on net global warming potential and greenhouse gas intensity from cropland soils. PLoS ONE, 11 (2), 1, 2016.
20. MOSIER A.R., HALVORSON A.D., REULE C.A., LIU X.J. Net global warming potential and greenhouse gas intensity in irrigated cropping systems in northeastern Colorado. Journal of Environment Quality, 35 (4), 1584, 2006.

21. VENTEREA R.T., BIJESH M., DOLAN M.S. Fertilizer source and tillage effects on yield-scaled nitrous oxide emissions in a corn cropping system. Journal of Environment Quality, 40 (5), 1521, 2011.

22. PITTELKOW C.M., ADVIENTO-BORBE M.A., HILL J.E., SIX J., VAN KESSEL C., LINQUIST B.A. Yieldscaled global warming potential of annual nitrous oxide and methane emissions from continuously flooded rice in response to nitrogen input. Agriculture, Ecosystems and Environment, 177, 10, 2013. 